\title{
The reality of the role of the Jordanian educational system in promoting international educational principles among secondary school students based on UNESCO principles
}

\author{
Hanan Mohammed Obiedat and Prof. Sinaria Kamil Abdel Jabbar \\ Faculty of educational sciences- educational leadership and foundations department, University of Jordan
}

\begin{abstract}
The present study sheds a light on role of the Jordanian educational system in promoting international educational principles among secondary school students based on UNESCO principles. The study consists from 660 female and male teachers who were selected through the random stratified sampling method. The questionnaire consists from 48 items and sheds a light on 5 areas. These areas are: 1)-international education to promote respect for human rights and freedoms, 2)- international education to promote tolerance and friendship among nations, 3)international education to preserve the environment, 4)- International education to promote justice and equality of opportunity between nations, 5)- education and international education to promote citizenship values.. The researchers found that the Jordanian educational system plays a moderate role in promoting international educational principles among secondary school students based on UNESCO principles. It was found that there isn't any significant differences between the respondents' attitudes which can be attributed to gender, academic qualification, and province. However, there is a significant difference in this regard which can be attributed to experience. When comparing the ones with 1-5 years and the ones with 11 years or more, the latter difference is for the favour of the ones with 11 years or more.
\end{abstract}

Keywords: International education, UNESCO, secondary schools, Jordanian educational system

DOI: $10.7176 / \mathrm{JEP} / 11-34-07$

Publication date: December $31^{\text {st }} 2020$

\section{Introduction:}

Nations exert much effort to educate people and promote principles and values among them. That is because having principles and values is essential to regulate behaviour. Principles and values are promoted through education. Due to the emergence of several problems and the technological developments in the world, it has become necessary to make developments to the field of international education. Through such developments, peace, and cooperation shall be promoted between various countries. Such developments shall promote respect for human rights and freedom.

The term (international education) emerged during World War I. It aims at increasing one's acceptance for the ones who belong to other countries (Abu Al-Wafa and Hussein, 2008). It may be defined as the education that aims at providing one with knowledge, skills, values and attitudes that allow him/her to adapt with the surrounding environment. It aims at promoting peace, cooperation, and respect for rights and freedoms (Ahmad and Mohammad, 2015). It aims at resolving conflicts and accepting the social and cultural diversity. It aims at avoiding the discrimination that's based on religion or ethnicity (Dahawi and Khater, 2014).

Based on UNESCO conference in 1974, international education aim at promoting a sense of belonging and friendship between various people. It also aims at promoting global peace and respect for others' freedoms and rights. It promotes justice and equality regardless of one's religion, language or ethnicity. It promotes equality in terms of obligations, job opportunities, and rights. It aims at protecting one's right to education, and promoting freedom of expression, and respect for others' religions. It aims at promoting a dialogue-based culture and respect for cultural diversity. It aims at developing people's co-existence skills, promoting tolerance and fighting against violence, hate and intolerance (Abed Al-Al, 2010).

International education promotes awareness about rights and duties in order to promote respect for dignity. It seeks developing people in cultural areas and engaging people in solving the problems of other communities. It aims at promoting awareness about the implications of colonialism and promoting global peace (Abed Al-Hay, 2013).

Due to having various goals for international education, various type of international education emerged. For instance, one of those types aims at fighting against violence and promoting tolerance. One of those types aims at fighting against the spread of weapons among civilians to promote security and encourage people to resolve conflicts peacefully. Another type aims at achieving sustainable development through promoting cooperation in this regard among countries. Another type aims at promoting citizenship, loyalty and belonging. Another type aims at protecting the global environment. Another type aims at promoting respect for cultural diversity, showing 
respect to the customs of others and preserving the cultural heritage (Ahmad, 2012). Based on the aforementioned information, international education aims at promoting peace, acceptance for other nations, and respect for human and child rights and cultural diversity. It aims at preserving the human heritage.

UNESCO was established in 1945 to address international educational issues and contemporary global issues related to educational programs. It provides much attention to language and art education. It aims at promoting a life-long learning approach and improving educational systems. It aims at promoting cooperation between people (Abed Al-Al, 2010).

UNESCO published numerous books, reports and periodicals on education, culture and communication. It aims at embedding international educational principles through curricula. It aims at performing further investigation for local, national, and international issues (Al-Buhi, 2014). It aims at:

1)-Delivering education to acquire knowledge

2)- Delivering education to achieve personal development

3)- Delivering education to acquire experience

4)- Delivering education to co-exist with others (Khalil, 2013).

It can be concluded that UNESCO exerts much effort to promote international educational principles through curricula. Educational system plays a significant in develop other systems and achieving advancement in society. Hence, governments have been providing much attention to the development of the educational system. Developing this system is necessary today to keep up with the latest development (Al-Khawaldeh and Al-Zyoodi, 2012).

Since 1987, the Jordanian government has been providing much attention to the development of the educational system. For instance, in the latter year, the conference titled (the educational development) was held to improve educational procedures. A plan was developed for improving education and shifting towards knowledge-based economy during the period (2013-2003). Another plan was developed for improving the outcomes of the educational system during the period (2016-2013). The Jordanian Ministry of Education provides secondary schools with addition attention due to their significance. That's because those school prepare students to join the labour market or the university (E'laimat and Naser, 2004).

However, more developments must be made to the secondary school stage. They are needed to develop secondary school students' skills, and cognitive capabilities and enable them to engage in the development of society. They are needed to promote a sense of responsibility among those students to make them handle their responsibilities towards their homeland (Al-Khawaldeh and Al-Zyoodi, 2012).

Due to the political, economic, social and cultural impacts of globalism, it was necessary to make changes to the educational system. Such changes include: promoting the international educational system (Abed Al-Hai, 2013). Statement of the Problem:

The researchers of the present study noticed that there is a need to promote global principles. Such global principles include: co-existing with others, tolerance and respect for cultural diversity. For instance, Al-Hroob (2013) found that the prevalence of the culture of peace in Jordanian secondary schools is moderate. He found that the Jordanian curricula don't promote the international educational principles among students. Tawalbeh (2019) adds that schools must promote such principles, like: tolerance, co-existence, and peace. Thus, the problem of this study is represented in exploring the role of the Jordanian educational system in promoting international educational principles among secondary school students based on UNESCO principles.

This study aimed to answer the questions below:

Q.1. What is the role of the Jordanian educational system in promoting international educational principles among secondary school students based on UNESCO principles from the teachers' perspective?

Q.2. Is there any statistically significant difference -at the statistical significance level of $(\mathrm{a}=0.05)$-between the respondents' attitudes which can be attributed to gender, experience, academic qualification, and province?

\section{The study's objectives:}

This study aimed to explore the role of the Jordanian educational system in promoting international educational principles among secondary school students based on UNESCO principles from the teachers' perspective. It aimed to explore whether there is any statistically significant difference - at the statistical significance level of $(a=0.05)$ between the respondents' attitudes which can be attributed to gender, experience, academic qualification, and 
province.

The study's significance

Theoretical Significance

This study is significant due to the significance of international educational principles, such as: cooperation, peace, and respect for rights and freedoms. Promoting such principles today is necessary for fighting against the violence that has been increasingly spreading. It is necessary due the increasing war.

\section{Practical significance:}

This study is beneficial for:

1)-The Ministry of Education: This study contributes to promoting awareness among officials in this ministry about the significance of promoting international educational principles among students in schools.

2)-Schools: This study encourage staff in school to develop programs for promoting international educational principles, such as: tolerance, and respect for minorities

3)-Researchers: This study assists researchers in developing a theoretical framework on international educational principles and UNESCO

\section{Limits:}

Thematic limits: This study sheds a light on the role of the Jordanian educational system in promoting international educational principles among secondary school students based on UNESCO principles from the teachers' perspective

Thematic limits: This study was conducted during the first semester of the academic year 2020/2021

Spatial limits: This study was conducted in several Jordanian public secondary schools

Human limits: This study targets a sample that consists from several Jordanian secondary public school teachers

\section{Definition of Terms}

International education: (Theoretical definition): It refers to the education that sheds a light on international aspects. It aims at promoting cooperation, and peace between nations and respect of human rights and duties (Ahmad, 2012).

International education: (operational definition): It refers to the education that aim at promoting international values. Such values include: dialogue, peace, tolerance, cooperation and mutual respect between nations. They include: respect for human rights, achieving justice and compliance with law. International education is investigated through the study's instrument

UNESCO principles: (Theoretical definition): They refer to a set of principles that were set by the UN. They include promoting global peace and security through delivering education. They include promoting compliance with the laws and respect for human rights and freedoms (Khalil, 2013).

UNESCO principles: (operational definition): They refer to all the principles that UNESCO aims to promote among people, such as: peace, respect for human rights, democracy, and peaceful co-existence. They are investigated through the study's instrument.

Educational system: (Theoretical definition): It refers to a set of ethics, principles, values that the Ministry of Education aims to promote. It involves the procedures and laws adopted by this ministry (E'laimat and Naser, 2004: 40).

Educational system: (operational definition): It refers to a set of elements and relationships derived from the political, economic and cultural system. Those elements and relationships are embedded in the goals of education Secondary school stage: (Theoretical definition): It refers to a school stage that aims at developing students' capabilities and knowledge and enabling students to join the labour market or university in order to meet the needs of the society (Law No. 3 of 1994 of the Ministry of Education)

\section{Previous Studies:}

Studies published in Arabic language:

De Monteen and Al-Sharaqi (2011) aimed to analyse official UNESCO documents and decisions during the period 1946-1999. They aimed to explore the relationship between such decisions and international education in curricula. They found that it's necessary to embed international educational principles in educational activities to reduce the severity of conflicts. They found that UNESCO tasks include delivering international education and promoting peace and co-existence. Performing this tasks requires holding conferences regularly

Lasheen and Abed Al-Hameed (2012) aimed to analyze the efforts exerted by universities to promote peace through education. They aimed to explore the requirements and goals of international education. They adopted a descriptive approach. 85 students were sampled. The researchers found that international education contributes to changing people's ideas and fighting against hate and violence. They found that such education contributes to 
promoting respect for human rights and overcoming the barriers hindering international cooperation

Al-Hroob (2013) aimed to explore the extent of prevalence of the culture of peace and the role of the administration in promoting this culture in the schools affiliated with UNESCO in Irbid. 54 teachers were sampled during the year (2012-2013) through using the random sampling method. A descriptive approach was adopted and a questionnaire was used. It was found that the extent of prevalence of the culture of peace in those schools is moderate.

Al-Asafi (2018) aimed to explore the role of student activities in promoting knowledge about human rights among students in the faculties of education in Iraq. He adopted a descriptive approach. He selected a sample that consists from 694 students from the faculty of education in Baghdad University. A questionnaire was used. SWOT analysis was conducted. It was found that student activities play a significant role in promoting knowledge about human rights among students in the faculties of education in Iraq

Al-Khodor and Al-Hyari (2018) investigated the role of curricula in promoting respect for international human rights among students in secondary schools in Kuwait. 650 secondary school teachers were sampled through the random sampling method. A descriptive approach was adopted. The researchers found that curricula play a moderate role in promoting respect for international human rights among students in secondary schools in Kuwait from the teachers' perspective.

Al-Aqrabawi (2019) aimed to propose an educational role for Jordanian public universities to promote international educational principles among students based on the ideas of Roger Garaudy. 400 students were sampled through the simple random sampling method. A questionnaire was used and a descriptive developmental approach was adopted. It was found that Jordanian public universities play a moderate role in promoting international educational principles among students from the perspective of those students. There isn't any significant differences between respondents' attitudes which can be attributed to gender or major. The severity of the challenges hindering Jordanian public universities from promoting international educational principles among students based on the ideas of Roger Garaudy is moderate.

\section{Studies published in English language:}

Wiliams aimed to explore the extent of embedding respect for human rights through social studies curricula of secondary schools in Alberta, Canada. He conducted a qualitative analysis for several social studies curricula. He found that the extent of embedding respect for human rights through such curricula is low.

Acosta (2011) aimed to explore the role of community college in California in delivering international education from the perspective of executive managers. He selected a sample consisting from 20 managers. He used a questionnaire and adopted an experimental approach. He found that international education has been developing much. He found that academic leaders have been playing a significant role in developing international education. Sung and Lin (2014) aimed to explore the extent of embedding peace-related concepts in the citizenship education curricula of the secondary school stage in Taiwan. He analysed the citizenship education curricula of $10^{\text {th }}$ and $11^{\text {th }}$ grades. An observational checklist was used. A content analysis was performed to analyse the content of the curricula. It was found that the extent of embedding peace-related concepts in the citizenship education curricula of the secondary school stage in Taiwan is low.

Groves et al. (2016) aimed to explore the extent of embedding concepts related to peace and democracy in the citizenship education curricula of $9^{\text {th }}, 10^{\text {th }}, 11^{\text {th }}$ and $12^{\text {th }}$ grades. A content analysis was performed to analyse the content of the curricula. The researcher found that the extent of embedding concepts related to peace the extent of embedding concepts related to democracy in the targeted curricula is moderate. He found that the extent of embedding concepts related to peace the extent of embedding concepts related to peace and war in the targeted curricula is low.

\section{Methodology:}

Approach:

The researchers adopted a descriptive survey-based approach. This study was conducted through the following procedures:

\section{Population:}

The population of the present study is represented in all the teachers who were working in the Jordanian secondary public schools during the academic year $(2020$ / 2021). It consists from 40100 female and male teachers. This number is obtained from the statistical data collected by the Ministry of Education for the academic year (2020/ 2021). 
Table (1): Data about the study's population:

\begin{tabular}{|c|c|c|c|c|}
\hline Province & City & Male teachers & $\begin{array}{r}\text { Female } \\
\text { teachers }\end{array}$ & Overall \\
\hline \multirow{5}{*}{$\begin{array}{l}\text { Southern } \\
\text { province }\end{array}$} & Province & 366 & 520 & 886 \\
\hline & Aqaba & 257 & 864 & 1121 \\
\hline & Karak & 1326 & 1613 & 2939 \\
\hline & Ma'an & 365 & 951 & 1316 \\
\hline & Overall & 2314 & 3948 & 6262 \\
\hline \multirow{5}{*}{$\begin{array}{l}\text { Northern } \\
\text { province }\end{array}$} & Irbid & 3188 & 4219 & 7407 \\
\hline & Mafraq & 1847 & 2567 & 4414 \\
\hline & Jarash & 672 & 940 & 1612 \\
\hline & Ajloon & 714 & 885 & 1599 \\
\hline & Overall & 6421 & 8611 & 15032 \\
\hline \multirow{6}{*}{$\begin{array}{l}\text { Central } \\
\text { province }\end{array}$} & Balqa & 1200 & 1673 & $* * * * * * * *$ \\
\hline & Zarqa & 1623 & 2491 & 4114 \\
\hline & Amman & 3953 & 6847 & 10440 \\
\hline & Madaba & 608 & 771 & 1379 \\
\hline & Overall & 7884 & 11422 & 18806 \\
\hline & Overall & 16119 & 23981 & 40100 \\
\hline
\end{tabular}

Source: The Ministry of Education

Sample:

The researchers selected 600 female and male teachers through using the random stratified sampling method. Those teachers were selected from 126 secondary schools. 54 schools are located in the Northern Province, 33 schools are located in the Central Province and 40 schools are located in the Southern Province. Table (1) presents the distributions of the members of the sample in accordance with gender, academic qualification, experience and province. 
Table (2): The distributions of the members of the sample in accordance with gender, academic qualification, experience and province

\begin{tabular}{|c|c|c|c|}
\hline Variable & Category & Frequency & Percentage \\
\hline \multirow[t]{4}{*}{ Gender } & \multirow[t]{2}{*}{ Male } & \multirow[t]{2}{*}{314} & \\
\hline & & & $48 \%$ \\
\hline & \multirow[t]{2}{*}{ Female } & \multirow[t]{2}{*}{345} & \\
\hline & & & $52 \%$ \\
\hline \multirow[t]{4}{*}{$\begin{array}{r}\text { Academic } \\
\text { qualification }\end{array}$} & \multirow[t]{2}{*}{$\begin{array}{r}\text { BA degree } \\
\text { or lower }\end{array}$} & \multirow[t]{2}{*}{464} & \\
\hline & & & $70 \%$ \\
\hline & \multirow[t]{2}{*}{$\begin{array}{r}\text { Postgraduate } \\
\text { degree }\end{array}$} & \multirow[t]{2}{*}{196} & \\
\hline & & & $30 \%$ \\
\hline \multirow[t]{6}{*}{ Experience } & \multirow[t]{2}{*}{$1-5$ years } & \multirow[t]{2}{*}{170} & \\
\hline & & & $26 \%$ \\
\hline & \multirow[t]{2}{*}{$6-10$ years } & \multirow[t]{2}{*}{228} & \\
\hline & & & $35 \%$ \\
\hline & \multirow[t]{2}{*}{$\begin{array}{r}11 \text { years or } \\
\text { more }\end{array}$} & \multirow[t]{2}{*}{262} & \\
\hline & & & $40 \%$ \\
\hline \multirow[t]{8}{*}{ Province } & \multirow[t]{2}{*}{$\begin{array}{r}\text { Central } \\
\text { Province }\end{array}$} & \multirow[t]{2}{*}{327} & \\
\hline & & & $50 \%$ \\
\hline & \multirow[t]{2}{*}{$\begin{array}{l}\text { Northern } \\
\text { Province }\end{array}$} & \multirow[t]{2}{*}{185} & \\
\hline & & & $28 \%$ \\
\hline & \multirow[t]{2}{*}{$\begin{array}{l}\text { Southern } \\
\text { Province }\end{array}$} & \multirow[t]{2}{*}{148} & \\
\hline & & & $22 \%$ \\
\hline & \multirow[t]{2}{*}{ Overall } & \multirow[t]{2}{*}{660} & \\
\hline & & & $100 \%$ \\
\hline
\end{tabular}

Instrument:

To meet the study's goals, the researchers developed a questionnaire based on several previous studies, such as: the ones conducted by Al- Aqrabawi (2019) and Tawalbeh (2019). This questionnaire aimed to explore the reality of the role of the Jordanian educational system in promoting international educational principles among secondary school students based on UNESCO principles.

\section{Validity:}

First: Content validity

The initial version of the questionnaire consists from 50 items. It was passed to 15 experts who work as faculty members. Those experts were chosen from the University of Jordan, Al-Balqa' Applied University (BAU), Al AlBait University and Amman Arab University. The researchers decided to keep the items that are approved by $80 \%$ of the experts. Based on the experts' views, changes were made. The final version of the questionnaire consists from 48 items.

Second: Construct validity

a)-Internal correlation between items and the areas they belong to:

The researchers passed the questionnaire forms to an exploratory sample that consists from 60 teachers. Those teachers weren't chosen from the actual sample. Then, the researchers measured the internal correlation coefficient 
values between items from one hand and the areas they belong to and the overall score from another hand

Table (3): The internal correlation coefficient values between items from one hand and the areas they belong to and the overall score from another hand

\begin{tabular}{|c|c|c|c|}
\hline Area & $\begin{array}{r}\text { Item } \\
\text { no. }\end{array}$ & \begin{tabular}{r}
\multicolumn{2}{c}{ Correlation } \\
with the \\
area
\end{tabular} & \begin{tabular}{rr}
\multicolumn{2}{|c|}{ Correlation } \\
with the \\
overall \\
score \\
\end{tabular} \\
\hline \multirow{9}{*}{$\begin{array}{l}\text { international education to promote respect for } \\
\text { human rights and freedoms }\end{array}$} & 1 & $.569 * *$ & $.200 * *$ \\
\hline & 2 & $.573 * *$ & $.154 * *$ \\
\hline & 3 & $.517 * *$ & $.131 * *$ \\
\hline & 4 & $.545 * *$ & $.520 * *$ \\
\hline & 5 & $.557 * *$ & $.560 * *$ \\
\hline & 6 & $.595 * *$ & $.529 * *$ \\
\hline & 7 & $.590 * *$ & $.543 * *$ \\
\hline & 8 & $.604 * *$ & $.478 * *$ \\
\hline & 9 & $.640 * *$ & $.525 * *$ \\
\hline \multirow{10}{*}{$\begin{array}{l}\text { international education to promote tolerance } \\
\text { and friendship among nations }\end{array}$} & 1 & $.519 * *$ & $.364 * *$ \\
\hline & 2 & $.666^{* *}$ & $.496 * *$ \\
\hline & 3 & $.637 * *$ & $.401 * *$ \\
\hline & 4 & $.698 * *$ & $.517 * *$ \\
\hline & 5 & $.713 * *$ & $.493 * *$ \\
\hline & 6 & $.674 * *$ & $.426 * *$ \\
\hline & 7 & $.676^{* *}$ & $.493 * *$ \\
\hline & 8 & $.630 * *$ & $.430 * *$ \\
\hline & 9 & $.707 * *$ & $.483 * *$ \\
\hline & 10 & $.612 * *$ & $.425 * *$ \\
\hline \multirow{5}{*}{$\begin{array}{l}\text { international education to preserve the } \\
\text { environment }\end{array}$} & 1 & $.339 * *$ & $.310 * *$ \\
\hline & 2 & $.441 * *$ & $.442 * *$ \\
\hline & 3 & $.698 * *$ & $.601 * *$ \\
\hline & 4 & $.576^{* *}$ & $.480 * *$ \\
\hline & 5 & $.680 * *$ & $.563 * *$ \\
\hline
\end{tabular}




\begin{tabular}{|c|c|c|c|}
\hline & 6 & $.718^{* *}$ & $.571 * *$ \\
\hline & 7 & $.699 * *$ & $.588 * *$ \\
\hline & 8 & $.715^{* *}$ & $.593 * *$ \\
\hline & 9 & $.696^{* *}$ & $.602 * *$ \\
\hline \multirow{10}{*}{$\begin{array}{l}\text { International education to promote justice and } \\
\text { equality of opportunity between nations, }\end{array}$} & 1 & $.698 * *$ & $.545^{* *}$ \\
\hline & 2 & $.764 * *$ & $.600 * *$ \\
\hline & 3 & $.695 * *$ & $.553 * *$ \\
\hline & 4 & $.766^{* *}$ & $.576 * *$ \\
\hline & 5 & $.792 * *$ & $.605^{* *}$ \\
\hline & 6 & $.781 * *$ & $.618^{* * *}$ \\
\hline & 7 & $.787 * *$ & $.605 * *$ \\
\hline & 8 & $.799 * *$ & $.630 * *$ \\
\hline & 9 & $.730 * *$ & $.561 * *$ \\
\hline & 10 & $.700 * *$ & $.630 * *$ \\
\hline \multirow{10}{*}{$\begin{array}{l}\text { education and international education to } \\
\text { promote citizenship values }\end{array}$} & 1 & $.554 * *$ & $.540 * *$ \\
\hline & 2 & $.632 * *$ & $.423 * *$ \\
\hline & 3 & $.614 * *$ & $.427 * *$ \\
\hline & 4 & $.633 * *$ & $.389 * *$ \\
\hline & 5 & $.651 * *$ & $.389 * *$ \\
\hline & 6 & $.643 * *$ & $.425^{* * *}$ \\
\hline & 7 & $.608^{* *}$ & $.463 * *$ \\
\hline & 8 & $.619 * *$ & $.426^{* * *}$ \\
\hline & 9 & $.622 * *$ & $.415^{* * *}$ \\
\hline & 10 & $.633 * *$ & $.439 * *$ \\
\hline
\end{tabular}

(*): This sign means that the value is significant at the statistical significance level of 0.01

Based on table (3), the overall values of correlation between the items and the overall score are within the range of $0.389-0.540$. They indicate that the internal construct validity of the instrument is high.

b)-Internal correlation coefficient values between the areas and the overall degree

The researchers measured the internal correlation coefficient values between the areas and the overall degree. Those values are listed in table (4): 
Table (4): The internal correlation coefficient values between the areas and the overall degree

\begin{tabular}{|c|c|c|c|c|c|}
\hline & $\begin{array}{l}\text { international } \\
\text { education to } \\
\text { promote respect for } \\
\text { human rights and } \\
\text { freedoms }\end{array}$ & $\begin{array}{l}\text { international } \\
\text { education to } \\
\text { promote tolerance } \\
\text { and friendship } \\
\text { among nations }\end{array}$ & $\begin{array}{l}\text { international } \\
\text { education } \\
\text { preserve to } \\
\text { environment }\end{array}$ & $\begin{array}{l}\text { International } \\
\text { education } \\
\text { promote justice and } \\
\text { equality of } \\
\text { opportunity between } \\
\text { nations }\end{array}$ & $\begin{array}{l}\text { education and } \\
\text { international } \\
\text { education to } \\
\text { promote citizenship } \\
\text { values }\end{array}$ \\
\hline $\begin{array}{l}\text { correlation } \\
\text { coefficient value }\end{array}$ & $.679 * *$ & $.693 * *$ & $.848^{* *}$ & $.788^{* *}$ & $.700 * *$ \\
\hline
\end{tabular}

$(* *)$ : This sign means that the value is significant at the statistical significance level of 0.01

Based on table (4), the internal correlation coefficient values between the areas and the overall degree are within the range of $0.679-0.0848$. They indicate that the construct validity of the instrument is high.

Reliability

To measure the reliability of the questionnaire, the researchers calculated the Cronbach alpha coefficient value for the areas. Those value are shown in table (5)

Table (5): The Cronbach alpha coefficient value for the areas

\begin{tabular}{|c|l|c|}
\hline No. & \multicolumn{1}{|c|}{ Area } & $\begin{array}{l}\text { Cronbach } \\
\text { coefficient value }\end{array}$ \\
\hline $\mathbf{1}$ & International education to promote respect for human rights and freedoms & 0.745 \\
\hline $\mathbf{2}$ & international education to promote tolerance and friendship among nations & 0.846 \\
\hline $\mathbf{3}$ & International education to preserve the environment & 0.810 \\
\hline $\mathbf{4}$ & $\begin{array}{l}\text { International education to promote justice and equality of opportunity between } \\
\text { nations }\end{array}$ & 0.914 \\
\hline $\mathbf{5}$ & Education and international education to promote citizenship values & 0.820 \\
\hline & Overall & $\mathbf{0 . 9 2 8}$ \\
\hline
\end{tabular}

Based on table (5), the overall Cronbach alpha coefficient value is 0.928 . The Cronbach alpha coefficient values of the areas are within the range of $0.745-0.914$. They indicate that the questionnaire is reliable.

Statistical analysis:

The researchers used the SPSS program. To answer the first question, they calculated means and standard deviations. To answer the second question, they calculated gender, academic qualification, years of experience and province, four way analysis of variance and sheffeh test were conducted.

\section{Results}

Results related to the first question

Q.1. What is the role of the Jordanian educational system in promoting international educational principles among secondary school students based on UNESCO principles from the teachers' perspective?

To answer the first question, means and standard deviations are calculated for areas. They are presented in table (6)

Table (6): means and standard deviations for the study's areas

\begin{tabular}{|c|c|l|c|c|c|}
\hline Rank & No. & \multicolumn{1}{|c|}{ Area } & Mean & Std. & Level \\
\hline 1 & 2 & $\begin{array}{l}\text { international education to promote } \\
\text { tolerance and friendship among } \\
\text { nations }\end{array}$ & 3.74 & 0.36 & High \\
\hline 2 & 5 & $\begin{array}{l}\text { Education and international education } \\
\text { to promote citizenship values }\end{array}$ & 3.72 & 0.33 & High \\
\hline 3 & 3 & $\begin{array}{l}\text { International education to preserve } \\
\text { the environment }\end{array}$ & 3.47 & 0.41 & Moderate \\
\hline 4 & 4 & $\begin{array}{l}\text { International education to promote } \\
\text { justice and equality of opportunity } \\
\text { between nations }\end{array}$ & 3.29 & 0.55 & Moderate \\
\hline 5 & 1 & $\begin{array}{l}\text { International education to promote } \\
\text { respect for human rights and } \\
\text { freedoms }\end{array}$ & 3.23 & 0.43 & Moderate \\
\hline & Overall & 3.49 & 0.31 & Moderate \\
\hline
\end{tabular}


Based on table (6), the Jordanian educational system plays a moderate role in promoting international educational principles among secondary school students based on UNESCO principles from the teachers' perspective. That's because the overall mean is 3.49 which is moderate. The mean of the (international education to promote tolerance and friendship among nations) is 3.74 which is high and ranked first. The mean of the (education and international education to promote citizenship values) is 3.72 which is high and ranked second. The mean of the (international education to preserve the environment) is 3.49 which moderate and ranked third. The mean of the (International education to promote justice and equality of opportunity between nations) is 3.29 which is moderate and ranked fourth. The mean of the (International education to promote respect for human rights and freedoms) is 3.23 which is moderate ad ranked last.

The latter results may be attributed to the significance of promoting tolerance among the members of the family and the members of the society. Tolerance can be promoted through listening to students and encourage students to have a dialogue. It can be promoted through media and educational institutions. Such institutions can promote respect for dignity and human rights.

Detailed results about each area are shown below

First: International education to promote respect for human rights and freedoms Means and standard deviations for the items of this area are presented in table (7)

Table (7): Means and standard deviations of the international education to promote respect for human rights and freedoms

\begin{tabular}{|c|c|c|c|c|c|}
\hline Rank & No. & Item & Mean & Std. & Level \\
\hline 1 & 7 & $\begin{array}{l}\text { I promote awareness about the significance } \\
\text { of enjoying the right of having access to good } \\
\text { food }\end{array}$ & 3.47 & 0.68 & Moderate \\
\hline 2 & 6 & $\begin{array}{l}\text { I engage students in the school assembly } \\
\text { speech to promote knowledge among them } \\
\text { about the Universal Declaration of Human } \\
\text { Rights. }\end{array}$ & 3.40 & 0.69 & Moderate \\
\hline 3 & 8 & $\begin{array}{l}\text { I encourage students to engage in the } \\
\text { activities that promote respect for human } \\
\text { rights }\end{array}$ & 3.37 & 0.74 & Moderate \\
\hline 4 & 5 & $\begin{array}{l}\text { I promote awareness about one's right to } \\
\text { obtain good healthcare services }\end{array}$ & 3.36 & 0.69 & Moderate \\
\hline 5 & 9 & $\begin{array}{l}\text { The school administration provides support } \\
\text { to the student activities related to laws }\end{array}$ & 3.34 & 0.73 & Moderate \\
\hline 6 & 4 & $\begin{array}{l}\text { I engage students in activities that promote } \\
\text { awareness about the right to education }\end{array}$ & 3.33 & 0.70 & Moderate \\
\hline 7 & 1 & $\begin{array}{l}\text { I provides students with knowledge about the } \\
\text { human rights acknowledged by the Jordanian } \\
\text { constitution }\end{array}$ & 3.17 & 0.75 & High \\
\hline 8 & 2 & $\begin{array}{l}\text { I provides students with knowledge about the } \\
\text { human rights acknowledged by the UN }\end{array}$ & 2.90 & 0.83 & High \\
\hline 9 & 3 & $\begin{array}{l}\text { Students conduct a comparison between the } \\
\text { human rights in the Jordanian constitution } \\
\text { and the human rights acknowledged by } \\
\text { global organizations }\end{array}$ & 2.71 & 0.88 & Moderate \\
\hline
\end{tabular}

Based on table (7), the means are within the range of 2.71-3.47. The mean of statement (7) is 3.47 which is high and ranked first. The latter statement states the following: (I promote awareness about the significance of enjoying the right of having access to good food). The latter result may be attributed to the significance of this right and its impact on the health of the members of the society. The mean of statement (9) is 2.71 which is moderate and ranked last. The latter statement states the following: (Students conduct a comparison between the human rights in the Jordanian constitution and the human rights acknowledged by global organizations).

Second: International education to promote tolerance and friendship among nations Means and standard deviations for the items of this area are presented in table (7) 
Table (8): Means and standard deviations of the international education to promote tolerance and friendship among nations

\begin{tabular}{|c|c|c|c|c|c|}
\hline Rank & No. & Item & Mean & Std. & Level \\
\hline 1 & 1 & $\begin{array}{l}\text { I promote awareness about the significance of (tolerance, } \\
\text { moderation, and empathy) in society }\end{array}$ & 3.87 & 0.38 & High \\
\hline 2 & 2 & $\begin{array}{l}\text { I promote negative attitudes towards violence, terrorism } \\
\text { and extremism }\end{array}$ & 3.84 & 0.46 & High \\
\hline 3 & 3 & $\begin{array}{l}\text { I promote awareness about the significance of showing } \\
\text { respect to the members of society }\end{array}$ & 3.84 & 0.45 & High \\
\hline 4 & 8 & I encourage students to engage in group activities & 3.78 & 0.50 & High \\
\hline 5 & 4 & $\begin{array}{l}\text { I promote acceptance for cultural diversity to develop } \\
\text { students' co-existence. }\end{array}$ & 3.77 & 0.55 & High \\
\hline 6 & 5 & $\begin{array}{l}\text { I develop students' communication skills to improve } \\
\text { students' capabilities of having dialogue with their } \\
\text { colleagues }\end{array}$ & 3.76 & 0.55 & High \\
\hline 7 & 7 & I develop students' communication and interaction skills & 3.73 & 0.55 & High \\
\hline 8 & 6 & $\begin{array}{l}\text { I encourage students to engage in the celebrations of } \\
\text { (national and global) events }\end{array}$ & 3.72 & 0.57 & High \\
\hline 9 & 9 & $\begin{array}{l}\text { I encourage people to hold symposiums to provide } \\
\text { students with opportunism to have dialogue with each } \\
\text { other }\end{array}$ & 3.66 & 0.61 & Moderate \\
\hline 10 & 10 & $\begin{array}{l}\text { I engage with students in the celebration of the } \\
\text { International Human Rights Day }\end{array}$ & 3.48 & 0.75 & Moderate \\
\hline
\end{tabular}

Based on table (8), the means are within the range of (3.48 - 3.87). The mean of statement (1) is 3.87 which is high and ranked first. The latter statement states the following: (I promote awareness about the significance of (tolerance, moderation, and empathy) in society). The latter result is attributed to the significance of tolerance, moderation, and empathy in society. The mean of statement (10) is 3.48 which is moderate and ranked last. The latter statement states the following: (I engage with students in the celebration of the International Human Rights Day).

Third: international education to preserve the environment

Means and standard deviations for the items of this area are presented in table (9)

Table (9): Means and standard deviations of the international education to preserve the environment

\begin{tabular}{|c|c|c|c|c|c|}
\hline Rank & No. & Item & Mean & Std. & Level \\
\hline 1 & 1 & $\begin{array}{l}\text { I encourage students to preserve the school } \\
\text { environment }\end{array}$ & 3.91 & 0.31 & High \\
\hline 2 & 2 & $\begin{array}{l}\text { I encourage students to engage in educational activities } \\
\text { to preserve the local environment }\end{array}$ & 3.80 & 0.47 & High \\
\hline 3 & 4 & $\begin{array}{l}\text { I promote awareness about the significance of } \\
\text { preserving the natural sources }\end{array}$ & 3.53 & 0.63 & Moderate \\
\hline 4 & 3 & $\begin{array}{l}\text { I encourage students to show attention to global issues } \\
\text { (e.g. drought, hunger and fighting against diseases) }\end{array}$ & 3.41 & 0.68 & Moderate \\
\hline 5 & 5 & $\begin{array}{l}\text { I promote awareness about the consequences of the } \\
\text { improper use of natural resources }\end{array}$ & 3.41 & 0.64 & Moderate \\
\hline 6 & 7 & $\begin{array}{l}\text { I promote awareness about the significance of } \\
\text { promoting environment-related ethics and } \\
\text { environmental awareness in society }\end{array}$ & 3.40 & 0.67 & Moderate \\
\hline 7 & 9 & $\begin{array}{l}\text { I encourage students to engage in activities that promote } \\
\text { environmental awareness }\end{array}$ & 3.35 & 0.81 & Moderate \\
\hline 8 & 6 & $\begin{array}{l}\text { I promote awareness about the significance of using } \\
\text { insecticides in a planned systematic manner }\end{array}$ & 3.21 & 0.75 & Moderate \\
\hline 9 & 8 & $\begin{array}{l}\text { I encourage students to find solutions for global } \\
\text { environmental problems (e.g. water pollutions and } \\
\text { desertification) }\end{array}$ & 3.20 & 0.70 & Moderate \\
\hline
\end{tabular}

Based on table (9), the means are within the range of (3.91 - 3.20). The mean of statement (1) is 3.91 which is high 
and ranked first. The latter statement states the following: (I encourage students to preserve the school environment). The latter result may be attributed to the significance of preserving the school environment. The mean of statement (8) is 3.20 which is moderate and ranked last. The latter statement states the following: (I encourage students to find solutions for global environmental problems (e.g. water pollutions and desertification). Fourth: International education to promote justice and equality of opportunity between nations Means and standard deviations for the items of this area are presented in table (10)

Table (10): Means and standard deviations of the international education to promote justice and equality of opportunity between nations

\begin{tabular}{|c|c|c|c|c|c|}
\hline Rank & No. & Item & Mean & Std. & Level \\
\hline 1 & 2 & $\begin{array}{l}\text { I promote awareness about the significance } \\
\text { of treating all people equally in terms of } \\
\text { law enforcement }\end{array}$ & 3.39 & 0.68 & Moderate \\
\hline 2 & 1 & $\begin{array}{l}\text { I promote knowledge about the meaning of } \\
\text { providing all nations with equal access to } \\
\text { opportunities to promote justice }\end{array}$ & 3.37 & 0.68 & Moderate \\
\hline 3 & 10 & $\begin{array}{l}\text { I encourage students to engage in the } \\
\text { activities that contribute to promoting } \\
\text { equality and justice among students }\end{array}$ & 3.33 & 0.71 & Moderate \\
\hline 4 & 5 & $\begin{array}{l}\text { I promote awareness about the significance } \\
\text { of giving all people access to educational } \\
\text { opportunities }\end{array}$ & 3.30 & 0.75 & Moderate \\
\hline 5 & 4 & $\begin{array}{l}\text { I promote awareness about the significance } \\
\text { of refraining from practicing } \\
\text { discrimination based on gender, religion or } \\
\text { ethnicity }\end{array}$ & 3.28 & 0.78 & Moderate \\
\hline 6 & 3 & $\begin{array}{l}\text { I promote awareness about the difference } \\
\text { between equality and justice }\end{array}$ & 3.26 & 0.70 & Moderate \\
\hline 7 & 6 & $\begin{array}{l}\text { I promote awareness about the significance } \\
\text { of distribution wealth fairly to all people }\end{array}$ & 3.25 & 0.76 & Moderate \\
\hline 8 & 7 & $\begin{array}{l}\text { I promote awareness about the significance of } \\
\text { providing all people with equal access to } \\
\text { opportunities to let them show their talents. } \\
\text { That shall develop the society }\end{array}$ & 3.24 & 0.77 & Moderate \\
\hline 9 & 8 & $\begin{array}{l}\text { I promote awareness about the positive } \\
\text { impact of providing students with equal } \\
\text { access to opportunities on promoting } \\
\text { creativity }\end{array}$ & 3.23 & 0.76 & Moderate \\
\hline 10 & 9 & $\begin{array}{l}\text { I promote awareness about the positive } \\
\text { impact of providing nations with equal } \\
\text { access to opportunities }\end{array}$ & 3.21 & 0.77 & Moderate \\
\hline
\end{tabular}

Based on table (10), the means are within the range of (3.21-3.39). The mean of statement (2) is 3.39 which is moderate and ranked first. The latter statement states the following: (I promote awareness about the significance of treating all people equally in terms of law enforcement). The latter awareness may be attributed to the significance of providing all people with their rights to equality. The mean of statement (9) is 3.21 which is moderate and ranked last. The mean of statement: (I promote awareness about the positive impact of providing nations with equal access to opportunities).

Fifth: education and international education to promote citizenship values.

Means and standard deviations for the items of this area are presented in table (11) 
Table (11): Means and standard deviations of the education and international education to promote citizenship values

\begin{tabular}{|c|c|c|c|c|c|}
\hline Rank & No. & Item & Mean & Std. & Level \\
\hline 1 & 4 & $\begin{array}{l}\text { I promote awareness about the } \\
\text { significance of (flag, and national } \\
\text { anthem) in promoting loyalty to } \\
\text { homeland }\end{array}$ & 3.81 & 0.47 & High \\
\hline 2 & 5 & $\begin{array}{l}\text { I promote awareness about solidarity } \\
\text { among Jordanians of all origins and } \\
\text { background }\end{array}$ & 3.80 & 0.49 & High \\
\hline 3 & 2 & $\begin{array}{l}\text { I encourage students to engage in } \\
\text { voluntary work that contribute to the } \\
\text { development of homeland }\end{array}$ & 3.78 & 0.49 & High \\
\hline 4 & 1 & $\begin{array}{l}\text { I promote knowledge among students } \\
\text { about their political and social rights and } \\
\text { duties }\end{array}$ & 3.76 & 0.51 & High \\
\hline 5 & 3 & $\begin{array}{l}\text { I promote awareness about the } \\
\text { significance of engaging in national } \\
\text { events that contribute to the development } \\
\text { of homeland }\end{array}$ & 3.73 & 0.51 & High \\
\hline 6 & 8 & $\begin{array}{l}\text { I promote awareness about the } \\
\text { significance of defending homeland }\end{array}$ & 3.73 & 0.52 & High \\
\hline 7 & 9 & $\begin{array}{l}\text { I promote awareness about the positive } \\
\text { impacts of preserving the public } \\
\text { properties }\end{array}$ & 3.70 & 0.56 & High \\
\hline 8 & 10 & $\begin{array}{l}\text { I encourage students to engage (national } \\
\text { events, programs and activities) }\end{array}$ & 3.69 & 0.54 & High \\
\hline 9 & 6 & $\begin{array}{l}\text { I promote awareness about the } \\
\text { significance of visiting famous } \\
\text { landmarks in Jordan to support internal } \\
\text { tourism }\end{array}$ & 3.65 & 0.59 & Moderate \\
\hline 10 & 7 & $\begin{array}{l}\text { I encourage students to use local products } \\
\text { to support the national economy }\end{array}$ & 3.50 & 0.66 & Moderate \\
\hline
\end{tabular}

Based on table (11), the means are within the range of (3.50-3.80). The mean of statement (4) is 3.81 which is moderate and ranked first. The latter statement states the following: (I promote awareness about the significance of (flag, and national anthem) in promoting loyalty to homeland). The latter result may be attributed to the significance of (flag, and national anthem). The mean of statement (7) is 3.50 which is moderate and ranked first. The latter statement states the following: (I encourage students to use local products to support the national economy)

Results related to the second question:

Q.2. Is there any statistically significant difference -at the statistical significance level of $(a=0.05)$-between the respondents' attitudes which can be attributed to gender, experience, academic qualification, and province?

To answer the first question, means and standard deviations are calculated to identify the respondents' attitudes in accordance with gender, experience, academic qualification, and province. Table (12) presents those values 
Table (12): Means and standard deviations to explore the respondents' attitudes in accordance with gender, experience, academic qualification, and province

\begin{tabular}{|c|c|c|c|c|c|c|c|}
\hline Gender & Category & Area & & & & & \\
\hline & & & $\begin{array}{l}\text { Internation } \\
\text { al } \\
\text { education } \\
\text { to promote } \\
\text { respect for } \\
\text { human } \\
\text { rights and } \\
\text { freedoms }\end{array}$ & $\begin{array}{l}\text { Internati } \\
\text { onal } \\
\text { educatio } \\
\mathrm{n} \quad \text { to } \\
\text { promote } \\
\text { toleranc } \\
\text { e and } \\
\text { friendshi } \\
\mathrm{p} \text { among } \\
\text { nations }\end{array}$ & $\begin{array}{l}\text { Internati } \\
\text { onal } \\
\text { educatio } \\
\mathrm{n} \text { to } \\
\text { preserve } \\
\text { the } \\
\text { environ } \\
\text { ment }\end{array}$ & $\begin{array}{l}\text { Internation } \\
\text { al } \\
\text { education } \\
\text { to promote } \\
\text { justice and } \\
\text { equality of } \\
\text { opportunit } \\
\text { y between } \\
\text { nations, }\end{array}$ & $\begin{array}{l}\text { Education } \\
\text { and } \\
\text { internation } \\
\text { al } \\
\text { education } \\
\text { to promote } \\
\text { citizenship } \\
\text { values.. }\end{array}$ \\
\hline \multirow[t]{4}{*}{ gender } & Male $(n=314)$ & Mean & 3.23 & 3.71 & 3.43 & 3.24 & 3.67 \\
\hline & & Std. & 0.430 & 0.374 & 0.395 & 0.504 & 0.337 \\
\hline & $\begin{array}{l}\text { Female } \\
(n=345)\end{array}$ & Mean & 3.23 & 3.77 & 3.50 & 3.33 & 3.76 \\
\hline & & Std. & 0.431 & 0.336 & 0.421 & 0.599 & 0.324 \\
\hline \multirow{4}{*}{$\begin{array}{l}\text { Academic } \\
\text { qualificati } \\
\text { on }\end{array}$} & $\begin{array}{l}\text { BA degree } \\
(\mathrm{N}=464)\end{array}$ & Mean & 3.21 & 3.77 & 3.45 & 3.23 & 3.73 \\
\hline & & Std. & 0.417 & 0.339 & 0.396 & 0.552 & 0.317 \\
\hline & $\begin{array}{l}\text { Postgraduate } \\
\text { degree } \\
(n=196)\end{array}$ & Mean & 3.27 & 3.68 & 3.52 & 3.41 & 3.68 \\
\hline & & Std. & 0.459 & 0.385 & 0.438 & 0.550 & 0.367 \\
\hline \multirow[t]{6}{*}{$\begin{array}{l}\text { Experienc } \\
\mathrm{e}\end{array}$} & $\begin{array}{l}1-5 \\
(\mathrm{n}=170)\end{array}$ years & Mean & 3.18 & 3.71 & 3.42 & 3.21 & 3.71 \\
\hline & & Std. & 0.450 & 0.417 & 0.430 & 0.554 & 0.359 \\
\hline & $\begin{array}{l}6-10 \quad \text { years } \\
(\mathrm{n}=228)\end{array}$ & Mean & 3.22 & 3.77 & 3.42 & 3.14 & 3.68 \\
\hline & & Std. & 0.403 & 0.332 & 0.375 & 0.501 & 0.343 \\
\hline & $\begin{array}{l}11 \text { years or } \\
\text { more }(n=262)\end{array}$ & Mean & 3.26 & 3.74 & 3.54 & 3.46 & 3.75 \\
\hline & & Std. & 0.438 & 0.331 & 0.416 & 0.557 & 0.303 \\
\hline \multirow[t]{6}{*}{ Province } & $\begin{array}{l}\text { Central } \\
\text { province } \\
(\mathrm{n}=327)\end{array}$ & Mean & 3.22 & 3.75 & 3.51 & 3.39 & 3.75 \\
\hline & & Std. & 0.465 & 0.338 & 0.408 & 0.561 & 0.305 \\
\hline & $\begin{array}{l}\text { Northern } \\
\text { province } \\
(\mathrm{n}=185) \\
\end{array}$ & Mean & 3.23 & 3.75 & 3.42 & 3.17 & 3.70 \\
\hline & & Std. & 0.398 & 0.362 & 0.398 & 0.522 & 0.322 \\
\hline & $\begin{array}{l}\text { Southern } \\
\text { province }(\mathrm{n}= \\
148)\end{array}$ & Mean & 3.25 & 3.71 & 3.43 & 3.19 & 3.65 \\
\hline & & Std. & 0.389 & 0.385 & 0.421 & 0.549 & 0.392 \\
\hline
\end{tabular}

Based on table (12), it appears that there are differences between the respondents' attitudes which can be attributed to gender, experience, academic qualification, and province. To explore whether those differences are statistically significant or not, the multivariate analysis of variance. Table (13) present the results of the latter analysis. 
Table (13): The results of the multivariate analysis of variance to identify whether the respondents' attitudes are statistically significant or not

\begin{tabular}{|c|c|c|c|}
\hline $\begin{array}{c}\text { Independent } \\
\text { variable }\end{array}$ & $\begin{array}{c}\text { Hotelling's } \\
\text { Trace }\end{array}$ & F value & Sig. \\
\hline Gender & 0.009 & 1.167 & 0.324 \\
\hline $\begin{array}{c}\text { Academic } \\
\text { qualification }\end{array}$ & 0.045 & 5.774 & $* 0.000$ \\
\hline Experience & 0.929 & 4.874 & $* 0.000$ \\
\hline Province & 0.952 & 3.206 & $* 0.000$ \\
\hline
\end{tabular}

(*): This sign means that the value is significant at the statistical significance level of 0.05

Based on table (13), there are statistically significant differences between the respondents' attitudes which can be attributed to experience, academic qualification, and province. However, there isn't any statistically significant difference between the respondents' attitudes which can be attributed to gender. To identify the ones whose the significant differences are for their favour, the four way analysis of variance was conducted. The results of the four way analysis of variance are shown in table (14)

Table (14): The results of the four way analysis of variance to identify the ones whose the significant differences are for their favour

\begin{tabular}{|c|c|c|c|c|c|c|}
\hline Source & Area & $\begin{array}{l}\text { Sum } \\
\text { squares }\end{array}$ & Df. & $\begin{array}{l}\text { Mean } \\
\text { square }\end{array}$ & F value & Sig. \\
\hline \multirow[t]{5}{*}{ Gender } & $\begin{array}{l}\text { International education to promote respect for human rights } \\
\text { and freedoms }\end{array}$ & 0.006 & 1 & 0.006 & 0.035 & 0.852 \\
\hline & $\begin{array}{l}\text { international education to promote tolerance and friendship } \\
\text { among nations }\end{array}$ & 0.465 & 1 & 0.465 & 3.753 & $\mathbf{0 . 0 5 3}$ \\
\hline & International education to preserve the environment & 0.167 & 1 & 0.167 & 1.018 & 0.313 \\
\hline & $\begin{array}{l}\text { International education to promote justice and equality of } \\
\text { opportunity between nations }\end{array}$ & 0.065 & 1 & 0.065 & 0.231 & 0.631 \\
\hline & $\begin{array}{l}\text { Education and international education to promote citizenship } \\
\text { values }\end{array}$ & 0.507 & 1 & 0.507 & 4.700 & 0.031* \\
\hline \multirow{5}{*}{$\begin{array}{l}\text { Academic } \\
\text { qualification }\end{array}$} & $\begin{array}{l}\text { International education to promote respect for human rights } \\
\text { and freedoms }\end{array}$ & 0.212 & 1 & 0.212 & 1.148 & 0.284 \\
\hline & $\begin{array}{l}\text { international education to promote tolerance and friendship } \\
\text { among nations }\end{array}$ & 1.271 & 1 & 1.271 & 10.266 & 0.001* \\
\hline & International education to preserve the environment & 0.242 & 1 & 0.242 & 1.478 & 0.224 \\
\hline & $\begin{array}{l}\text { International education to promote justice and equality of } \\
\text { opportunity between nations }\end{array}$ & 1.892 & 1 & 1.892 & 6.757 & $0.010 *$ \\
\hline & $\begin{array}{l}\text { Education and international education to promote citizenship } \\
\text { values }\end{array}$ & 0.383 & 1 & 0.383 & 3.556 & 0.060 \\
\hline \multirow[t]{5}{*}{ Experience } & $\begin{array}{l}\text { International education to promote respect for human rights } \\
\text { and freedoms }\end{array}$ & 0.553 & 2 & 0.277 & 1.495 & 0.225 \\
\hline & $\begin{array}{l}\text { international education to promote tolerance and friendship } \\
\text { among nations }\end{array}$ & 0.653 & 2 & 0.326 & 2.637 & $\mathbf{0 . 0 7 2}$ \\
\hline & International education to preserve the environment & 1.346 & 2 & 0.673 & 4.106 & $0.017 *$ \\
\hline & $\begin{array}{l}\text { International education to promote justice and equality of } \\
\text { opportunity between nations }\end{array}$ & 9.391 & 2 & 4.696 & 16.773 & 0.000* \\
\hline & $\begin{array}{l}\text { Education and international education to promote citizenship } \\
\text { values }\end{array}$ & 0.489 & 2 & 0.245 & 2.269 & 0.104 \\
\hline \multirow[t]{2}{*}{ Province } & $\begin{array}{l}\text { International education to promote respect for human rights } \\
\text { and freedoms }\end{array}$ & 0.185 & 2 & 0.093 & 0.501 & 0.606 \\
\hline & $\begin{array}{l}\text { international education to promote tolerance and friendship } \\
\text { among nations }\end{array}$ & 0.160 & 2 & 0.080 & 0.647 & 0.524 \\
\hline
\end{tabular}




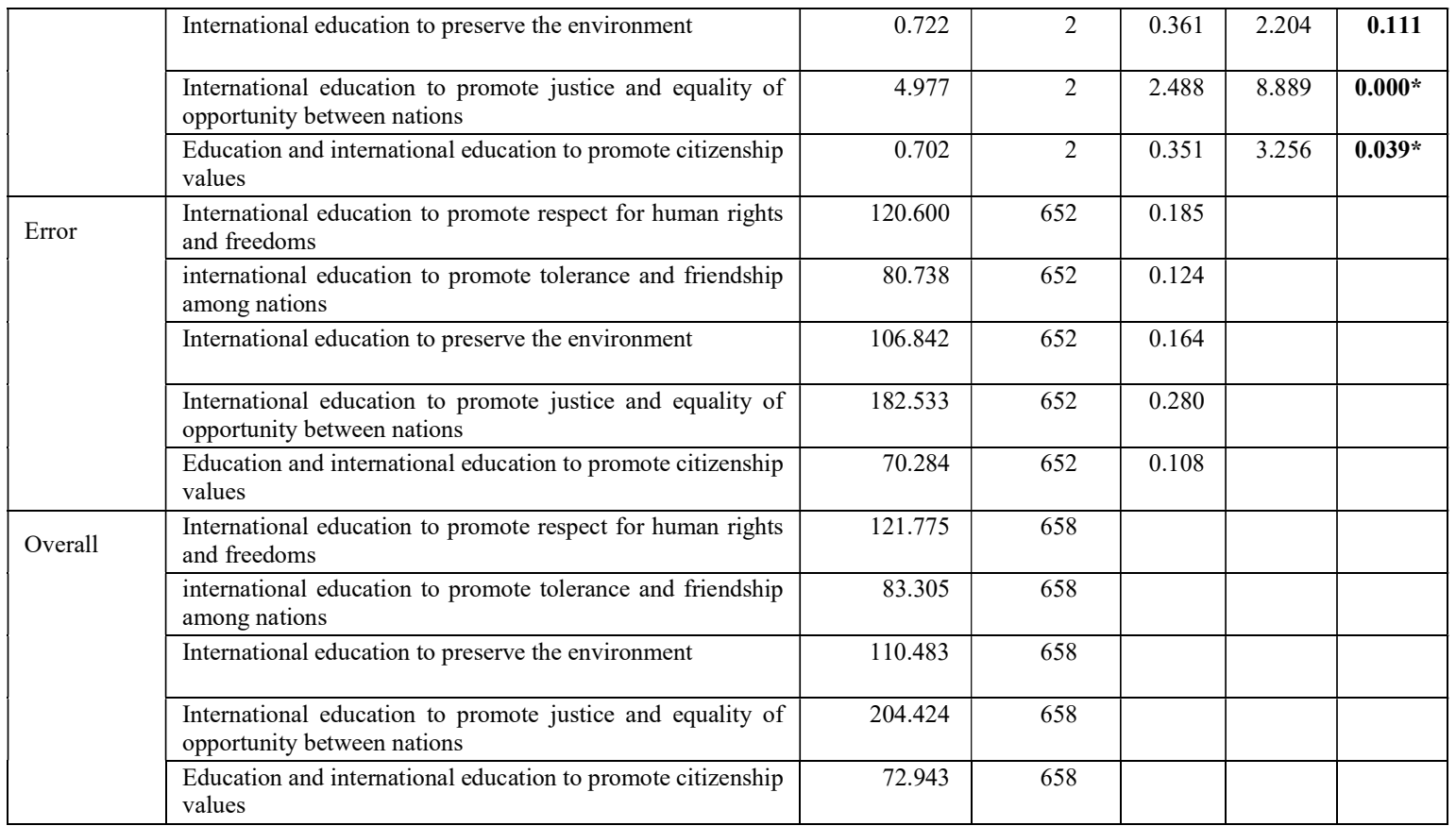

$(*)$ : This sign means that the value is significant at the statistical significance level of 0.05

Based on table (14), there isn't any significant difference between respondents' attitudes that can be attributed to gender in terms of (international education to promote respect for human rights and freedoms, international education to promote tolerance and friendship among nations, international education to preserve the environment and international education to promote justice and equality of opportunity between nations). That's because the fvalues are $0.035,3.753,1.018$ and 0.231 respectively. Those values aren't statistically significant. However, there is a significant difference between respondents' attitudes that can be attributed to gender in terms of (education and international education to promote citizenship values). That's because the f-value is 0.4 .70 which isn't statistically significant. The latter differences are for the favour of females. The latter result may be attributed to the fact that females have better abilities to deal with students. Having such abilities shall contribute to promoting positive attitudes towards homeland and society.

Based on table (14), there isn't any significant difference between respondents' attitudes that can be attributed to academic qualification in terms of International education to promote respect for human rights and freedoms, international education to preserve the environment and education and international education to promote citizenship values. That's because the relevant f-values are: $1.148,1.478$ and 3.556 respectively. Those values aren't statistically significant.

Based on table (14), there is a significant difference between respondents' attitudes that can be attributed to academic qualification in terms of international education to promote tolerance and friendship among nations, and international education to promote justice and equality of opportunity between nations. That's because the relevant f-values are: 10.266 and 6.757 respectively. Those values are statistically significant. The difference in terms of international education to promote tolerance and friendship among nations is for the favour of the holders of BA degree. The latter result may be attributed to the fact that BA holders realize the significance of friendship and tolerance more than others. The difference in terms of international education to promote justice and equality of opportunity between nations is for the favour of the holders of postgraduate degrees. The latter result may be attributed to the fact that holders of postgraduate degrees have more intellectual maturity than others.

Based on table (14), there isn't any significant difference between respondents' attitudes that can be attributed to experience in terms of international education to promote respect for human rights and freedoms, international education to promote tolerance and friendship among nations and education and international education to promote citizenship values. That's because the relevant f-values are $1.495,2.637$ and 2.269 respectively. Those values aren't statistically significant. There is a significant difference between respondents' attitudes that can be attributed to experience in terms of international education to preserve the environment and international education to promote justice and equality of opportunity between nations. That's because the relevant $\mathrm{f}$-values are 4.106 and 16.733 respectively. Those values are statistically significant. To explore the ones whose the experience-related 
differences are for their favor, Sheffeh test was conducted. The results of Sheffeh test are shown in table (15) below

Table (15): The results of Sheffeh test to explore the ones that the experience-related differences are for their favor

\begin{tabular}{|l|r|r|r|}
\hline & Category & 6-10 years & 11 years or more \\
\hline $\begin{array}{l}\text { international education } \\
\text { to preserve the } \\
\text { environment }\end{array}$ & 1-5 years & & $-0.1206^{*}$ \\
\cline { 2 - 4 } & $6-10$ years & & $-0.1234^{*}$ \\
\hline $\begin{array}{l}\text { International education } \\
\text { to promote justice and } \\
\text { equality of opportunity } \\
\text { between nations }\end{array}$ & 6-10 years & & $-0.2530^{*}$ \\
\cline { 2 - 4 } & & & $-0.3308^{*}$ \\
\hline
\end{tabular}

$(*)$ : This sign means that the value is significant at the statistical significance level of 0.05

Based on table (15), there is a significant difference between respondents' attitudes that can be attributed to experience in terms of international education to preserve the environment and international education to promote justice and equality of opportunity between nations. When comparing the ones with 1-5 years and the ones with 11 years or more, the latter difference is for the favour of the ones with 11 years or more. When comparing the ones with 6-10 years and the ones with 11 years or more, the difference is for the favour of the ones with 11 years or more. There isn't any difference between the ones with 1-5 years and the ones with 6-10 years. The results in this regard may be attributed to the fact that experience enables one to understand the significance of justice and equality of opportunity

Based on table (14), there isn't any significant difference between respondents' attitudes that can be attributed to province in terms of (international education to promote respect for human rights and freedoms, international education to promote tolerance and friendship among nations and international education to preserve the environment). That's because the relevant f-values are: $0.501,0.647$, and 2.204 respectively. Those values are not statistically significant. Based on table (14), there is a significant difference between respondents' attitudes that can be attributed to province in terms of (international education to promote justice and equality of opportunity between nations and education and international education to promote citizenship values). That's because the relevant f-values are: 8.889 , and 3.256 respectively. Those values are statistically significant. To explore the ones whose the province-related differences are for their favor, Sheffeh test was conducted. The results of Sheffeh test are shown in table (15) below

Table (16): The results of Sheffeh test to explore the ones that the province -related differences are for their favor

\begin{tabular}{|c|c|c|c|}
\hline Area & Category & $\begin{array}{l}\text { Northern } \\
\text { province }\end{array}$ & Southern province \\
\hline \multirow{2}{*}{$\begin{array}{l}\text { international } \\
\text { education to } \\
\text { promote justice } \\
\text { and equality of } \\
\text { opportunity } \\
\text { between nations }\end{array}$} & $\begin{array}{l}\text { Central } \\
\text { province }\end{array}$ & $* 0.2226$ & $0.2000^{*}$ \\
\hline & $\begin{array}{l}\text { Northern } \\
\text { province }\end{array}$ & & -0.0226 \\
\hline \multirow{2}{*}{$\begin{array}{l}\text { education and } \\
\text { international } \\
\text { education to } \\
\text { promote } \\
\text { citizenship values }\end{array}$} & $\begin{array}{c}\text { Central } \\
\text { province }\end{array}$ & 0.0501 & $0.1031 *$ \\
\hline & $\begin{array}{l}\text { Northern } \\
\text { province }\end{array}$ & & 0.2530 \\
\hline
\end{tabular}

$(*)$ : This sign means that the value is significant at the statistical significance level of 0.05

Based on table (16), there is a significant difference between respondents' attitudes that can be attributed to province in terms of (international education to promote justice and equality of opportunity between nations). When comparing the ones in the Central Province with the ones in the Northern Province, the latter difference is for the favour of the ones in the Central Province. When comparing the ones in the Central Province with the ones in the Southern Province, the latter difference is for the favour of the ones in the Central Province. There isn't any difference between the ones in the Southern Province and the ones in the Northern Province. The results in this 
regard may be attributed to the fact that there are many problems facing the ones residing in the Central Province. Facing such problems requires preserving the environment

Based on table (16), there is a significant difference between respondents' attitudes that can be attributed to province in terms of education and international education to promote citizenship values. When comparing the ones in the Central Province with the ones in the Southern Province, the latter difference is for the favour of the ones in the Southern Province. There isn't any difference between the ones in the Northern Province and the ones in the Central Province. There isn't any difference between the ones in the Southern Province and the ones in the Northern Province. The results in this regard indicate that the ones residing in the Southern Province have a strong sense of belonging to homeland. Having such as strong sense of belonging shall make people keen on preserving the environment of homeland.

To explore the respondents' attitudes in accordance with gender, academic qualification, experience and province in terms of all the areas jointly, means and standard deviations are calculated. They are shown below in table (17):

Table (17): means and standard deviations to explore the respondents' attitudes in accordance with gender, academic qualification, experience and province in terms of all the areas jointly

\begin{tabular}{|r|r|r|r|r|}
\hline Variable & Category & Frequency & Mean & Std. \\
\hline \multirow{2}{*}{ Gender } & Male & 314 & 3.46 & 0.299 \\
\cline { 2 - 5 } & Female & 345 & 3.53 & 0.319 \\
\hline $\begin{array}{r}\text { Academic } \\
\text { qualification }\end{array}$ & BA degree or lower & 464 & 3.49 & 0.294 \\
\cline { 2 - 5 } & Postgraduate degree & 196 & 3.52 & 0.334 \\
\hline Experience & $1-5$ years & 170 & 3.45 & 0.276 \\
\cline { 2 - 5 } & 6-10 years & 228 & 3.45 & 0.315 \\
\cline { 2 - 5 } & 11 years or more & 262 & 3.56 & 0.311 \\
\hline Province & Central Province & 327 & 3.53 & 0.294 \\
\cline { 2 - 5 } & Northern Province & 185 & 3.46 & 0.324 \\
\cline { 2 - 5 } & Southern Province & 148 & 3.45 & \\
\hline
\end{tabular}

Based on table (17), it appears that there are differences between the respondents' attitudes in accordance with gender, academic qualification, experience and province in terms of all the areas jointly. To explore whether those differences are significant or not, four way analysis of variance was conducted. The results of this analysis are shown in table (18) below

Table (18): The results of the four way analysis of variance to explore the differences between the respondents' attitudes in accordance with gender, academic qualification, experience and province in terms of all the areas jointly

\begin{tabular}{|r|c|r|r|l|c|}
\hline Source & Sum of squares & Df. & Mean square & F value & Sig. \\
\hline Gender & 0.189 & 1 & 0.189 & 2.017 & 0.156 \\
\hline Academic qualification & 0.010 & 1 & 0.010 & 0.109 & 0.741 \\
\hline Experience & 1.203 & 2 & 0.601 & 6.413 & $0.002^{*}$ \\
\hline Province & 0.507 & 2 & 0.254 & 2.704 & 0.068 \\
\hline Error & 61.146 & 652 & 0.094 & & \\
\hline Overall & 63.849 & 658 & & & \\
\hline
\end{tabular}

$(*)$ : This sign means that the value is significant at the statistical significance level of 0.05

Based on table (18), there isn't any statistically significant difference -at the statistical significance level of $a=0.05$ - between the respondents' attitudes which can be attributed to gender. That's because the relevant f-value 
is 2.017 which isn't statistically significant. There isn't any statistically significant difference -at the statistical significance level of a $=0.05$ - between the respondents' attitudes which can be attributed to academic qualification. That's because the relevant f-value is 0.109 which isn't statistically significant.

There isn't any statistically significant difference - at the statistical significance level of a $=0.05$ - between the respondents' attitudes which can be attributed to province. That's because the relevant f-value is 2.704 which isn't statistically significant. However, there is a statistically significant difference -at the statistical significance level of $\mathrm{a}=0.05$ - between the respondents' attitudes which can be attributed to experience. That's because the relevant f-value is 6.423 which is statistically significant. To identify the ones whose the experience-related differences are for their favour, Sheffeh test was conducted. The results of this test are shown in table (19) below.

Table (19): The results of Sheffeh test to identify the ones whose the experience-related differences are for their favour

\begin{tabular}{|r|r|r|r|}
\hline $\begin{array}{r}\text { Overall } \\
\text { areas } \\
\text { jointly }\end{array}$ & Categories & 6 -10 years & 11 years or more \\
\hline Overall & $1-5$ years & 0.0018 & $-0.1066^{*}$ \\
\cline { 2 - 4 } & 6-10 years & & $-0.1083^{*}$ \\
& & & \\
\hline
\end{tabular}

(*): This sign means that the value is significant at the statistical significance level of 0.05

Based on table (19), there is a statistically significant difference - at the statistical significance level of a $=0.05$ between the respondents' attitudes which can be attributed to experience. When comparing the ones with 1-5 years and the ones with 11 years or more, the latter difference is for the favour of the ones with 11 years or more. When comparing the ones with 6-10 years and the ones with 11 years or more, the difference is for the favour of the ones with 11 years or more. There isn't any difference in terms of attitudes between the ones with 1-5 years and the ones with 6-10 years.

Recommendations:

The researchers recommend:

1)- Exerting effort to promote knowledge among academics in schools and universities about international education

2)- Providing academics with more training courses in the aim of promoting knowledge about international education

3)- Activating the role of academics in promoting international educational principles

4)-Promoting cooperation between various educational institutions to develop curricula and embed international educational principles in them

\section{References}

References Published in Arabic Language:

Abu Al-Wafa, J.; and Hussein, S. (2008). International education and globalizing education. Egypt. Dar Al-Jame’a Al-Jadeedeh

Ahmad, I. (2012). International education. Cairo. Dar Al-Feker Al-Arabi

Ahmad, S. and Mohammad, F. (2015). Introduction to international education. Cairo, Egypt. Dar Al-Sahab

Al-Buhi, F. (2014). International education. Alexandria, Dar Al-Ma'refah

Horoob, D. (2013). The Role of School Management in the Dissemination Peace Culture and their Application in the Jordanian Secondary School Affiliated to UNESCO in Irbid Governorate. Unpublished PhD dissertation. Yarmouk University. Irbid. Jordan. 
Al-Khodor, B. and Al-Hyari, H. (2018). The role of educational curricula in providing high school students with the universal principles of human rights as perceived by teachers in the State of Kuwait. Dirasat: Educational Sciences. 45(1), 220-235

Khalil, N. (2013). International education: fundamentals and applications. Cairo. Dar Al-Fajer

De Monteen, K. and Al-Sharaqi, D. (2011). Development of the concept (international education): Sixty years from the history of UNESCO. Futures Journal. The Center of UNESCO Publications. Egypt. 4(41). 881901

Al-Khawaldeh, T and Al-Zyoodi, M. (2012). The Jordanian educational system during the third millennium. Jordan. Dar Al-Ham.

Dahawi, B. and Khater, M. (2014). Contemporary international education. Egypt. Cairo. Dar Al-Feker Al-Arabi

Tawalbeh, H. (2019). The Contribution Degree of Jordanian Sport in Confirmation Value and Educational Concepts on a Citizenship. Dirasat: Educational Sciences. 46(2),249-266

Abed Al-Hai, R. (2013). Global education: A requirement during the third millennium. Amman. Dar Al-Warraq

Abed Al-Al, H. (2010). A comparative study targeting the affiliated studies in terms of foreign expertise in Egypt. The Journal of Education. Egypt. 13(29), 288-30

Abed Al-Fattah, M. (2001). The impact of international education on the Egyptian educational system: An analytical study and a future vision. The Journal of Psychological and educational Research- The faculty of education in Menoufiya University. Egypt, 16(1), 263-294

Al-Asafi, M. (2018). The role of school activities in promoting knowledge about human rights among the female students enrolled in the faculties of education in Iraqi universities. The Journal of Studies on History and Civilizations. 10(34).536-557)

Al-Aqrabawi, Y. (2019). A proposed educational role for Jordanian public universities to promote international educational principles among students based on the ideas of Roger Garaudy. Unpublished PhD dissertation. The University of Jordan. Amman. Jordan.

E'laimat, M. and Naser, S. (2004). The Jordanian educational system. Jordan. Dar Al-Shorooq.

Lasheen, M. and Abed Al-Hameed, M. (2012). Methods for promoting the culture of peace-based education through university education in the light of international educatioanl requirements. The Journal of the Faculty of Education. Banha University. 73(42). 27-91

Naser, I. (2011). Educational sociology. Amman. Jordan. Dar Wa'el.

The Ministry of Education (2019). The act of the Ministry of Education No. 3 of 1994

\section{References Published in English language:}

Acosta.MC (2011). The Role of International Education In California Community Colleges: Perspectives of College Leaders. Doctor of Education, Pepperdine University.

Groves, T \& Barone, M\& Lanina, H. (2016). Civic education and visions of war and peace in the Spanish transition to democeacy. Paedogogica Historica 52, (1), 169-187.

Gundogd,K. (2010).The Effect of Constructivist Instruction on prospective teachers' Attitudes toward Human Rights Education Electronic Journal of Research in Educational Psychology,8, (1)333-352, ERIC, EJ890540.

Mcleod, L. (2014). A peaceful pedagogy: Teaching Human Rights Across the Curriculum, Procedia- Social and Behavior Science, 52,(12) 125, 132.

Sung, M \& Lin, C. (2014). An Investigation of Taiwan Imaga in spain High School Socail Studies Texbooks: persctives of Peace Education Journal of Texbook Research, 7(3), 67-99.

William, F. (2001). Children's Rights in the social studies curriculum, social education, 1. (56). 203-204. 